\section{結果}

内リンパ震は三つの部分にその解剖学的位唒䦔係より 分けられている、すなわち，前庭部に近い部をproximal partと言い，中間部を intermediate partまたは， rugose part と茟っている，硬膜に接する部を distal partといい，この部方要状になっている。こ扎らの三つ の部分はいずれの動物に打いても、ほぼ同様な細胞表面 粠造をしていた。

一般的には rugose part が最む細胞学的に與味のある 所で，今回は特にこの部に焦点をあわせて観察した。

まず proximal partでは，前庭部の細胞之同様に表面が 平坦な細胞で抬抬われ，1ヌ、ネコ，モルモットなどでは centrioleを向つ細胞が観察されたが，ヒトでは centriole をもつ細胞はほとんどみられなかった，表面荤造から は，紐胞境界飞短い microvilli がみられるが，平坦な細 胞表面には microvilli 委少ないようであった。

ヒトの rugose partは, 細胞学的に興味ある所見がみ られ、ドーム状の microvilli の少ない絪胞と, microvilli の長い細胞が湿在していた。これらの細胞恃明， 暗細胞として区別されている。この明，暗細胞は，暗細 胞が osmium で濃染される事から，この様に名つけb

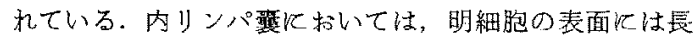
いmicrovilli がみられるのが特徴とされて括り，この microvilli の先端にはしばしば, cell debrisな゙゙が付着 している所晃がみられ， Pinocytotic な機能があるう 飞考えられている。また，ドーム状細胞で，microvilli

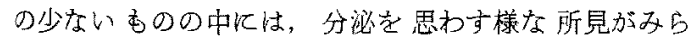
れ，この細胞については次回，X線マイクロアナライザ 一飞称いて，その成分を分析する予定である，病理組織 学的には，ムコポリサッ力ライド槏の物質が，細胞表面 にポリ一プ状にみられるという報告もある。従って，こ れらの分泌を思わす細胞蒜面のS (硫黄) の分析などを 行えば，興味ある所見が得られるかもしれない，

ヒトではこの rugose partはイヌ，キルもットなど他 の動物の様に，ドーム様の緗朌と microvilliの長い細胎

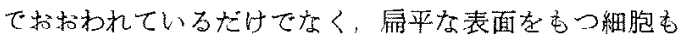
みられ，また，湅胞表面の力なり大きな細胞むみられ，
一種類のみの細胞にわける事恃出来なかった。

イヌでは，rugose part の細胞配列はきわわて特異な 形態を示し, distal の sac portion 飞向って流れるよう なパターンをしていた、すなわも，ドーム状で紡鍂状の

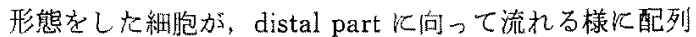
し，その閒に， microvilli の長い細胞が混在していた。 この様にドーム状に膨㓌した細胞と，長い microvilli 羊つ細胞はどの動物汇拉いてもみられ，共通した所見て あった。

炏に distal part の細胞は一般に艺の表面は平坦な程 迠であった。しかし，ヒトでは，硬膜に接した矮状のこ

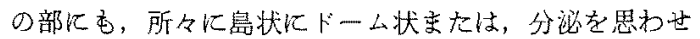
しるるような細胞群が存在するのがみられた。しかし， 他の動物では，一般に平坦な表面を毛つ緗胞で扣招われ てい节よろであり，この部は，むしる，队リンバ液を貯 溜するために存在しているかのよらな所見であった。

SM 処置を行った，モルモットの rugose partは，特

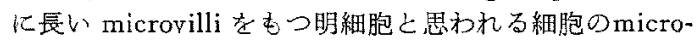
villi の尖端が，混棒状をなしていて， microvilli の短 䋧，末たは，球状变化したものがみられた。これが直 ちに，SMによる影留とはいえないが，SMの汢射によ り, 前庭ならびにコルチ器の感觉上皮の变化加起るの子

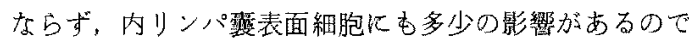
はないのかと推測出来るような所見も克られた。 今後，

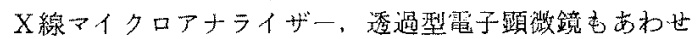
て用いる事により，内リンパ翼の機能が，上り詳細にわ 加るものと思われるので, さらに形態学的に追求して行 くつもりである。

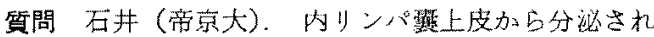
ることはとト側頭骨加ら李推测できたが，演者の SEM 听見でこのように分泌している細胞は相当に多いのか.

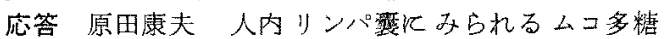
は, やはり，内リンパ䇛 rugous part の細胞加ら分必 されるものと思われる.今後，X線マイクロアナライザ 一によりSの墨なをど分析してみる予定である。

(B 82-1108-24010)

\title{
136. Fine structure of the tissue lining the cochlear perilymphatic space
}

\author{
Franke $\mathrm{K}$. and Yajin $\mathrm{K}$.
}

\section{Summary.}

The perilymphatic tissue of the chinchilla inner ear was studied by help of the thin-section and the freeze-fracture methods.

The perilymphatic space is bordered by thin tissue with two to five layers of extremely flat and extended cells. Their protoplasms are coupled electrotonically and metabolically by communicating junctions. The intercellular space is closed against the perilymphatic space by zonulae occludentes among the perilymphatic cells of the round window membrane and by fasciae occludentes at the bony labyrinthine capsule. The latter do not surround the cells completely, however occurring between the cells of any layer in any depth of the perilymphatic tissue they altogether can be considered as tight. 
In comparison with similar studies of the meninges there is concluded that the perilymphatic tissue can be considered as arachnoidal tissue too.

質問 中井戔明 (大饭市大). I congratulate Dr.
Franke on your fine study. Concerning with round window membrane, is there any permeability between perilymph and middle ear space?

(B 32-1109-23010)

\title{
137. 側頭骨含気腔と前庭水管外口の左右比較, 及び前庭水管外口の年路変化
}

\author{
村㸸龍太郎・江上徹也・村息二郎・隅上秀伯（長崎大）
}

31 例の病理解剖屍休より得た左右の倒頭䝂62耳につい て合気整（以下Pn.と略す）の発育程度亡前庭水管外口 (以下 A.V. と略す) の長经の左右比較老行うととす火

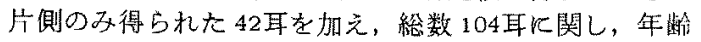

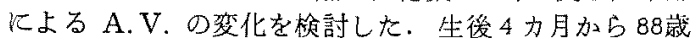
までの31例，62耳のPn.の発省程度の左石差をシュ一ラ 一法レントゲン写真，または肉眼的所見によって検討す 万と同時に A.V. の曼佳を計測した。31例中Pn. の発 育程度に左右差の認められたものが17例, 左右 $\mathrm{Pn}$. 発達 が同程度のものが14例であった，前者のうち Pn. 良好 側の A.V. 驾不良例のそれより大きいものが12例, 逆 K Pn. 不最側の A.V. 加Pn. 良好側のそれより大きい

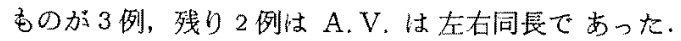
Pn, 発達が左右同程度の14例について A.V. の左右差老 みてみると9例怯左右差有り，5例住 A.V. 左右同長で あった。

A.V.の年鮯变化の钼祭儿は上記の62耳に片側の夕得 られた 42 耳を加え総検体数 104 耳を使用した．A.V.D 開口部位は 1 藏以下の乳児では成人に比し前上方奇りて あり成長するに徒い後下方になり $\mathrm{S}$ 状洞儿近くなってい た.A.V.の長径は10藏ないし20藏程度まで堌大する
ようであるが，30藏以上は变化しないようだった。ま た，A．V，長径は成長とともに大きくなるが個体差も生 してきていた.

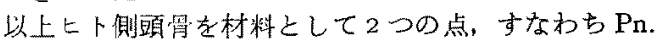

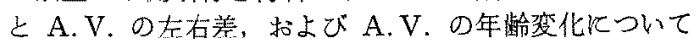

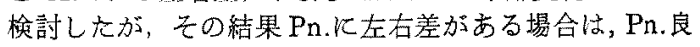
好側の A.V.が他側の A.V.より大きいことが多いが， Pn。発育が左右同程度の場合でも A.V. K左右差がある ことがかなりの程度あった．A，V．の年略变化について

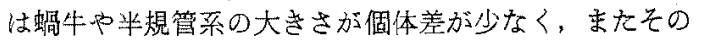
発育毛胎生中期汇ほとえど完成されるのにくらべ，内り ンパ管，内リン八褯を被も骨の出口である A.V. は生 後ある一定年䀫まで大きさを增し同時に個体差が生じて くる。これらのことは A.V.が被む内りンハ管，内リ ンパ㢣の機能を知るうえで與味深く思われた。

質問 野村恭也 (東大). 左右差をみる場合, 側頍骨 自体の大きさ，S状静脈洞との距離との関係はどうか。

心管 村惼笔太郎 側頭骨白体の大きさは今回は特に 注目してない，閒口部位の变化を示すには基隼となる点 を定め数倠で表現する必要吕あると思うが，今徭㭘討し たい.

(B 82-1110-24010)

\section{8. 感音性難聴の一病態}

（盖膜 性 感 音 性 難 聴）

喜多村 健・鳥山稔・田内 光・四口 哲（国立病院医療せンタ一）

石井哲大（帝索大）・野村恭也（東大）

はじめに

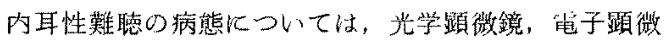
鏡を用いて, 有毛細胞, 支持細胞, ラセン神経節細胞, 骨ラセン板神経束などの变化が指摘されている.今回わ

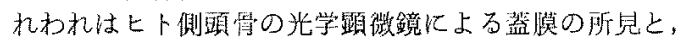
生前の恥力を比較倹討し, 堪膜の病変を主とした感音性 難聴の存在について検討した。

症例 1

55歳で繁不全で治療中に心筋硬塞で死亡した男子．49

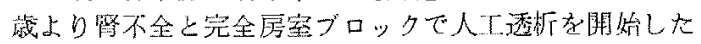
が，聴力心正常であった。透析開始後 2 年目 (51藏)よ
り高音澌傾型の難恥が比現した，この難㯖は保存的治療 て改善傾问を示したが，死亡9カ月前には融び增悪し， 死亡5 月月前の聼力は, 雨耳とも $250,500 \mathrm{~Hz}$ て $20 \mathrm{~dB}$, $1 \sim 2 \mathrm{kHz}$ で $40 \sim 50 \mathrm{~dB}, 4 \mathrm{kHz}$ で $55 \mathrm{~dB}, 8 \mathrm{kHz}$ て $80 \mathrm{~dB}$ の高音濑倾型の聴力損失を示した。倒或骨内耳の組織所

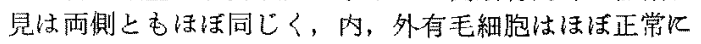
保たれていた。しかし，箩膜は萎縮し薄くなって扣り一 部トンネルの上に癄着している状態であった・ラセン神 経節細胞, 血管条火は買常䜣見は認めbれず，高音濑傾

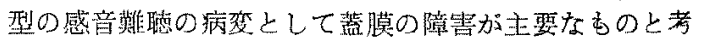
无机。 